\title{
Eucalyptus ESTs involved in mechanisms against plant pathogens and environmental stresses
}

\author{
Daniel Dias Rosa ${ }^{1,3}$; Edson Luiz Furtado ${ }^{1,3}$; Leonardo Pires Boava ${ }^{1}$; Celso Luis Marino ${ }^{2}$; Edson Seizo Mori ${ }^{1,3}$; $\operatorname{Iraê}^{1}$ \\ Amaral Guerrini ${ }^{1,3}$; Edivaldo Domingues Veline ${ }^{1,3}$; Carlos Frederico Wilcken ${ }^{1,3}$
}

\author{
${ }^{1}$ Universidade Estadual Paulista - UNESP, Faculdade de Ciências Agronômicas, Botucatu-SP; ${ }^{2}$ UNESP, Instituto de Biociências, Botucatu-SP; \\ ${ }^{3}$ Bolsista do CNPq-Brasil. \\ Autor para correspondência: Edson Luiz Furtado (elfurtado@fca.unesp.br.) \\ Data de chegada: 03/01/2008. Aceito para publicação em: 29/05/2010.
}

1553

\section{ABSTRACT}

Rosa, D.D.; Furtado, E.L.; Boava, L.P.; Marino, C.L.; Mori, E.S.; Guerrini, I.A.; Veline, E.D.; Wilcken, C.F. Eucalyptus ESTs involved in mechanisms against plant pathogens and environmental stresses. Summa Phytopathologica, v.36, n.4, p.282-290, 2010.

Eucalypt plantation has high economical importance in Brazil; however, it has been attacked by various pathogens under different environmental stress conditions. Disease resistance and survival under unfavorable environmental conditions have revealed that the eucalypt has developed highly efficient defense systems. Here we show the results of the Eucalyptus ESTs Genome Project (FORESTs). Using the expressed sequence tags (ESTs) obtained by the Project, contigs of similar sequences from each cDNA library induced and not induced by stress agents were formed, and cDNA sequences similar to other already known molecules, such as plant-signaling molecules, phytoalexins, lignin biosynthesis pathways, PR-proteins and putative genes corresponding to enzymes involved in the detoxification of reactive oxygen species, were identified. We also present general considerations about the mechanisms of Eucalyptus defense against biotic and abiotic stresses. These data are of extreme importance for future eucalypt breeding programs aimed at developing plants with enhanced resistance against pathogens and environmental stresses.

Palavras-chave adicionais: Eucalyptus, resistance, phytoalexins, PR-proteins.

\section{RESUMO}

Rosa, D.D.; Furtado, E.L.; Boava, L.P.; Marino, C.L.; Mori, E.S.; Guerrini, I.A.; Veline, E.D.; Wilcken, C.F. ESTs de Eucalyptus envolvidos nos mecanismos contra fitopatógenos e estresse ambiental. Summa Phytopathologica, v.36, n.4, p.282-290, 2010.

A cultura do Eucalipto tem importância econômica muito elevada no Brasil e vem sofrendo inúmeros ataques de patógenos, além de essa cultura estar sujeita aos inúmeros estresses ambientais. A resistência e sobrevivência desta cultura frente às circunstâncias ambientais desfavoráveis, e ataques de pragas e doenças, revelaram que o Eucalipto apresenta um sistema de defesa evoluído e altamente eficiente. Aqui nós apresentamos os resultados obtidos no projeto do genoma de ESTs do Eucalyptus (FORESTs). Agrupando as seqüências de cDNA expressas (ESTs) obtidas pelo projeto, montou-se grupos (contigs) de seqüências similares provenientes de cada biblioteca de cDNA induzidas e não induzidas por agentes estressantes, identificou-se os grupos de seqüências de cDNA similares a outras moléculas já conhecidas, como moléculas de plantas-sinalizadoras, fitoalexinas e biossíntese de vias de lignina, proteínas-RP e supostos genes correspondendo às enzimas envolvidas na detoxificação de moléculas de oxigênio reativo. Apresentamos também, considerações gerais sobre os mecanismos de defesa do Eucalipto contra o estresse biótico e abiótico. Estas informações são de extraordinário valor para a produção de Eucalipto e ajudaram no futuro a direcionar programas de melhoramento do Eucalipto, visando assim obter plantas com melhor resistência contra os patógenos e estresses ambientais.

Keywords: Eucalyptus, resistência, fitoalexinas, Proteínas-RP.

Several defense mechanisms against pathogen attack are known for plants. Each of these mechanisms is controlled by a different set of genes, some of which have been almost completely identified. These mechanisms can be divided into two groups: those depending on hostpathogen interactions (resistance genes) and those related to unspecific response to pathogens, phytoalexins, PR-proteins etc. (12).

Currently, genes belonging to the gene-to-gene system proposed by Flor (15) can be divided into two groups, one group has a coding region for leucine-rich repeats (LRRs) and the other group has a coding region for a nucleotide binding site (NBS). These domains can be involved in the plant-pathogen recognition mechanism and these proteins recognize extracellular products of avirulence (avr) genes considered elicitors by the host (5).

The class of resistance genes is characterized by the presence of LRRs and protein-kinase function, with absence of a NBS, including, for example, the wheat LR10 gene of resistance to Puccinia (14).

Nowadays, the expressed sequence tag (EST) sequencing allows the analysis of expressed genes and has accelerated gene discovery. The establishment of putative functions for ESTs by means of comparisons with genes and sequences, the functions of which are already known, is very important to learn defense mechanisms. These hypotheses can be tested in functional genomic procedures and the 
results may help the plant breeding process. ESTs can also be useful probes for mapping studies (19).

The aim of this study was to identify in the Eucalyptus EST Bank (FORESTs) ESTs of high similarity to genes involved in the plant defense mechanism against biotic and abiotic stresses (Figure 1). Understanding the genetic basis of these defense mechanisms will help the genetic improvement of those traits in Eucalyptus.

\section{MATERIALAND METHODS}

The Eucalyptus genome project (FORESTs) (16) was developed for a consortium of four Brazilian Forest Companies and the State of São Paulo Research Foundation (FAPESP). It had the participation of 20 laboratories from São Paulo network, called AEG (https:// forests.esalq.usp.br), obtaining 123,889 reads. All sequences used during this work are derived from cDNA libraries specific to different tissues, organs or growth conditions of the species E. grandis, E. globulus, E. saligna and E. urophylla. The libraries were constituted of wood (WD), bark (BK), floral buttons (FB), leaves (LV), seedlings (SL), stem (ST), root (RT), and callus (CL) (https:// forests.esalq.usp.br/Librariesinfo.html).

DNA sequences coding for proteins and enzymes involved in the Eucalyptus defense mechanism against biotic and abiotic stresses were searched by using a BLAST-P program with a threshold of E-value < $10^{-46}(3)$. Each sequence coding for these proteins, which were used for analysis, was from the National Center for Biotechnology Information (NCBI) and the protein was analyzed by using the TBLASTN program (3) against Eucalyptus EST clusters. Once the corresponding putative protein of the Eucalyptus cluster was obtained, it was again aligned by comparing the BLASTX program to NCBI in order to check the sequences.

\section{RESULTS AND DISCUSSION}

Cell surface communications and signaling system

The plant cell wall is the first line of defense against any potential pathogen and environmental changes. Spores from a number of pathogenic fungi produce or are coated with adhesive material in order to attach to the plant surface. During germination, a germ tube grows across the plant surface, often in response to specific environmental conditions and locations. A variety of strategies are adopted to enter the host, including the elaboration of a specialized infection cell, the appresorium.

The cuticular layer is composed of surface wax and a hydroxy fatty acid polymer named cutin (26). The latter has 2 large families of monomer compounds consisting of $\mathrm{C} 16$ and $\mathrm{C} 18$ chains. Uchiana \& Okuyama (50) identified two major cutin components which induced appresorium formation at nanomolar concentrations and fungal behavior after alterations in the carbon chain of the fatty acid.

Sweigard et al. (49) suggested that various funguses secrete cutinases on the leaf surface, and the extracellular cutinase may promote the release of cutin monomers which may bind to a specific subcellular receptor, inducing the appresorium formation.

A number of conserved pathways are involved in transducing signals from the environment to the cells. They are controlled by molecules such as cyclic nucleotides, $\mathrm{Ca}^{++}$and phosphoinositides. Extacellular signals are transduced via protein-protein interactions (35). Reversible covalent modifications of proteins through

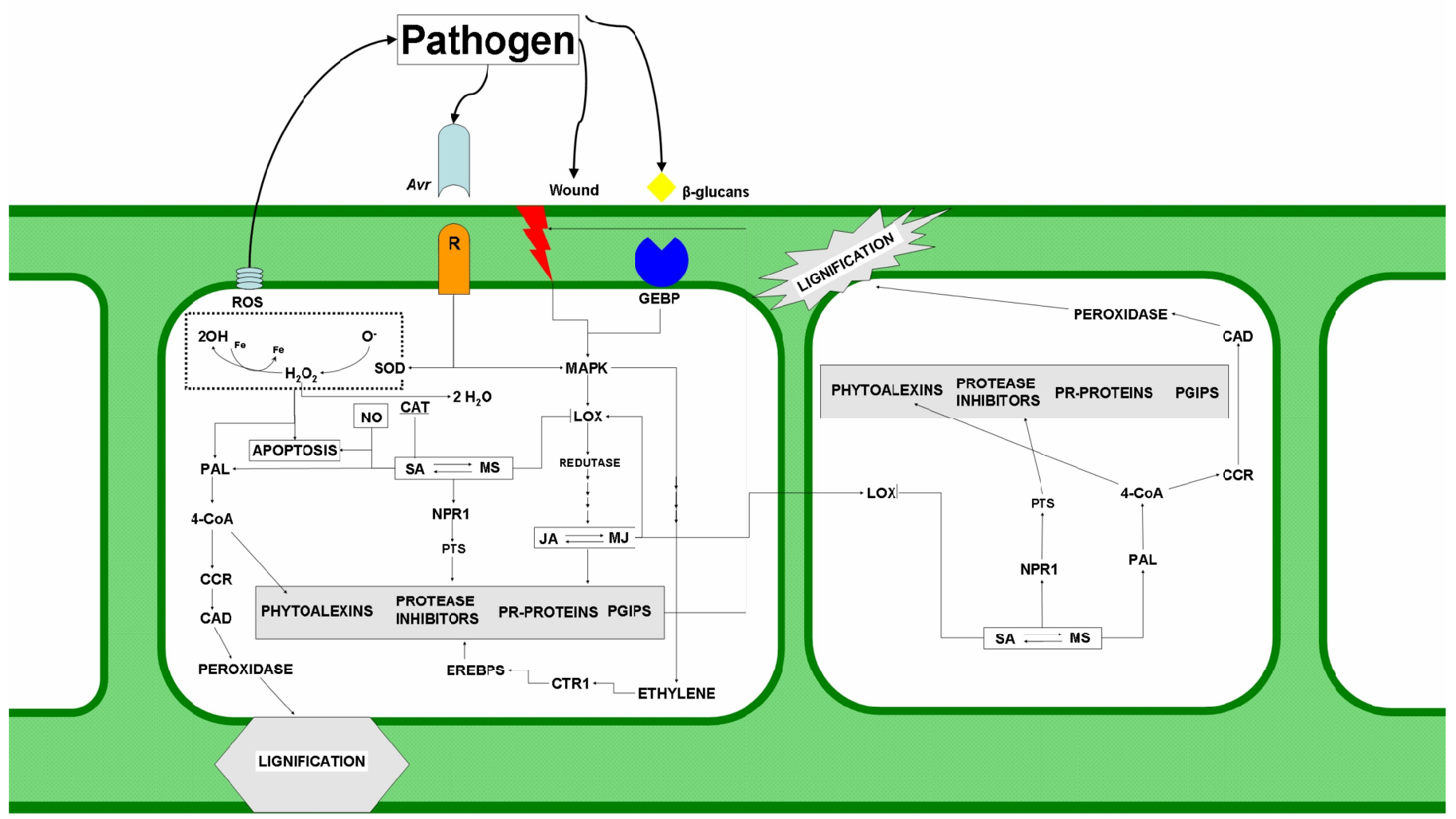

Figure 1. Schematic representation of the induction of defense protein gene expression. Eucalyptus sp. cell defense responses include disease-resistant genes (R), a variety of involved mechanisms such as bursts of oxidative reactions (CAT, SOD), phytoalexin, lignin, ethylene, salicylic acid (SA), jasmonate (JA), cell death (apoptosis), proteinase inhibitors and production of pathogenesis-related proteins. Filled arrows illustrate portions of the pathway proposed from direct evidence and interactions. 
phosphorylation mediated by the opposing reactions of kinases and phosphatases, as well as the analogous exchanges of phosphate potentials in GTP-binding proteins, play essential roles in signal transduction. The membrane receptors responsible for the pathogenhost specificity are similar to the kinase receptor-like proteins (RPK) found in animals and plants (28). RPK proteins have three main domains: a) extracelullar domain with leucine-rich repeats (LRR) and leucine zipper motif (LZ) involved in recognition and protein-protein interaction; b) transmembrane domain (hydrophobic) related to membrane binding; and finally c) intracelullar domain with catalytic function (kinase). Resistance genes are divided into classes. The first class corresponds to genes encoding for LRR proteins and nucleotide binding site (NBS) with or without the LZ region. The NBS-LRR type comprises genes containing both a 5' terminal NBS and a 3 ' terminal LRR of various lengths.

In our search at the FORESTs database, we found genes homologous to LRR and NBS-LRR-type resistant protein, HV1LRR1 and HV1LRR2, RPM1disease resistance protein, RPR1h protein, LRK1 protein, and L-zip+NBS+LRR protein (Table 1). The second class, with a kinase and/or a LRR domain, is represented by $C f-2, C f$ 4, $C f-9, X a-21$, and Pto genes, which have a 5' LRRs and/or a serine/ threonine kinase domain (4). Evidence supports that the highly variable LRRs in both classes of $\mathrm{R}$ genes may play a role in pathogen recognition, providing a structural backbone that has been modified over evolution in response to the variation in $A v r$ gene products from the pathogens (39). Those enzymes are easily localized because they have a transmembrane domain. The proteins encoded by Pto, Xa21 and Fen genes have a catalytic site (kinase) in the $\mathrm{C}$-terminal protein portion, which is probably involved in the protein phosphorilation during the signal transduction. In the FORESTs databank, there are EST sequences similar to kinases and/or a LRR-resistant gene type domain, and the EST clusters are similar to receptor-like serine/threonine kinase of A. thaliana and MAP3K protein kinases of A. thaliana and Oryza sativa (Table 1).

In plants, salicylic acid (SA) is involved in various physiological processes like stomatal closure, flowering induction and heat production; it also plays a central role in the defense against pathogen attack. To date, plant genes known to be induced by SA are not primary response genes; instead, they respond later and are dependent on new protein synthesis. This class of genes is exemplified by pathogenesis-related (PR) proteins, such as PR-1, PR-2, PR-3, PR-4 and PR-5 (53). The biosynthetic pathway of SA appears to begin with the conversion of phenylalanine into transcinnamic acid (t-CA) catalyzed by phenylalanine ammonia-lyase (PAL).

The plant hormone ethylene is synthesized during several development stages, including seed germination and ripening; it is also produced in response to infections by pathogens and injuries by herbivores (48). Ethylene plays an important role in plant defense to pathogen attacks as one of the systemic signal transducers (1). It activates the transcription of defense-related genes of PR proteins (48), which are widely distributed in plants and are toxic to invading pathogens. The biosynthesis of ethylene is largely understood. 1amino-cyclopropane-1-carboxylic acid (ACC) synthase and ACC oxidase play a main role in ethylene synthesis. ACC synthase catalyzes the conversion of S-adenosyl-L-methionine (SAM) into ACC, and ACC oxidase converts ACC into ethylene, carbon dioxide and cyanide (13). EST clusters related to the enzymes ACC synthase and ACC oxidase involved in the biosynthesis of ethylene, are present in the eucalypt database (Table 2).

Ecker (13) proposed the following model for ethylene response pathway: ethylene may bind to and activate the receptor, likely inactivating CTR1, which codes for a product that acts as a negative regulator of the ethylene response pathway, allowing the product of EIN2 gene to activate a number of terminal ethylene regulated genes, possibly acting on genes like EIN3 and ERFs. The enzyme coded by CTR1 has kinase functions, which is important to its actions in the phosphorylation cascade in ethylene signaling events. A homolog to CTR1 of Arabidopsis thaliana is present in FORESTs database (Table 2). Predicted eucalypt amino acids similar to ERFs (EREBPs) were found in the databank.

The ethylene-responsive defense genes are PR-2 (glucanases), PR-3, PR-4, PR-8 and PR-11 (chitinases). The substrates for those types of enzymes, chitinases and glucanases suggest that they act against cell walls of fungi and bacteria (51). These data indicate that the ethylene biosynthesis and response in eucalypt are very similar to those in other plants.

Ethylene is a volatile plant hormone of multiple functions. It is known to be synthesized in response to injuries or infections by pathogens (7).

Kieber et al. (24) examined a million A. thaliana plants and observed

Table 1. Eucalyptus putative homologous genes involved with biotic and abiotic resistance at FORESTs database.

\begin{tabular}{|c|c|c|c|c|}
\hline Putative genes & Species & FORESTs number & NCBIAccession & E-value \\
\hline LRR receptor-like protein kinase & Arabidopsis thaliana & EGSBRT3120G04.g & 7269703 & $2 \mathrm{e}^{-79}$ \\
\hline Hv1LRR 1 & Hordeum vulgare & EGCECL1282E03.g & 5669778 & $6 e^{-34}$ \\
\hline Hv1LRR2 & Hordeum vulgare & EGCECL1282E03.g & 5669782 & $6 e^{-38}$ \\
\hline RPM1 homolog disease resistance protein & Sorghum bicolor & EGCECL1282E03.g & 4680207 & $2 \mathrm{e}^{-37}$ \\
\hline RPR $1 \mathrm{~h}$ & Oryza sativa & EGCECL1282E03.g & 4519938 & $3 \mathrm{e}^{-34}$ \\
\hline LRK1 protein & Oryza sativa & EGEPCL2204D05.g & 22093632 & $3 \mathrm{e}^{-80}$ \\
\hline L-zip+NBS+LRR & Oryza sativa & EGSBSL7030E12.g & 4519258 & $4 e^{-27}$ \\
\hline Receptor-like Serine/threonine kinases & Arabidopsis thaliana & EGSBSL7030E12.g & 4519258 & $4 e^{-27}$ \\
\hline MAP3K epsilon kinase protein & Arabidopsis thaliana & EGJERT3184A07.g & 15231910 & $1 \mathrm{e}^{-119}$ \\
\hline MAPK mitogen-activated protein kinase & Oryza sativa & EGABRT3014F10.g & 7328530 & $2 \mathrm{e}^{-14}$ \\
\hline Ser/Tre kinase Ctr 1 protein & Arabidopsis thaliana & EGBGBK1051A06.g & Q05609 & 0.0 \\
\hline Kinase protein & Arabidopsis thaliana & EGABLV2279DA01.g & 22474449 & $1 \mathrm{e}^{-160}$ \\
\hline
\end{tabular}


Table 2. Eucalyptus putative homologous genes involved with plant signaling molecules at FORESTs database.

\begin{tabular}{|c|c|c|c|c|}
\hline Putative genes & Species & FORESTs number & NCBIAccession & E-value \\
\hline Lipoxygenase & Arabidopsis thaliana & EGEZST7215D11.g & 20259579 & $2 \mathrm{e}^{-116}$ \\
\hline Lipoxygenase & Solanum tuberosum & EGEZLV1202D12.g & 6689343 & $1 \mathrm{e}^{-125}$ \\
\hline Allene oxide synthase & Lycopersicon esculentum & EGACLV3272B08.g & 7677378 & $3 e^{-67}$ \\
\hline Allene oxide cyclase & Lycopersicon esculentum & EGQHRT6038H05.g & 15797681 & $2 \mathrm{e}^{-68}$ \\
\hline 1-aminocyclopropane-1-carboxylate synthase & Triticum aestivum & EGCERT6019F05.g & 1173638 & $9 \mathrm{e}^{-81}$ \\
\hline 1-aminocyclopropane-1-carboxylate synthase & Oryza sativa & EGCERT6019F05.g & 6006360 & $4 \mathrm{e}^{-81}$ \\
\hline 1-aminocyclopropane-1-carboxylate oxidase & Oryza sativa & EGJFSL4202G05.g & 23495703 & $2 \mathrm{e}^{-42}$ \\
\hline 1-aminocyclopropane-1-carboxylate oxidase & Phyllostachys edulis & EGABLV2282G06.g & 12862572 & $1 \mathrm{e}^{-100}$ \\
\hline Ethylene-response protein - ERS & Oryza sativa & EGSBRT6210E05.g & 15054446 & $2 \mathrm{e}^{-101}$ \\
\hline Serine/Threonine-Protein Kinase CTR1 & Rosa (hybrid cultivar) & EGBGBK1051A06.g & AAK40361 & 0.0 \\
\hline Transcription factor EREBP1 & Oryza sativa & EGABLV2285C11.g & 6689918 & $3 e^{-46}$ \\
\hline
\end{tabular}

some mutants that were not affected by ethylene, stopping reacting to its presence or inhibiting it, which tends to alter the growth. These mutants don't have the gene that commands the production of the enzyme protein kinase, which adds a protein phosphatic group. The gene of protein-kinase is similar to that of enzymes of plants, animals and men, which suggests a universal link among how messages are interpreted.

Jasmonic acid (JA) and its methyl ester (MeJA) derivative are compounds that occur simultaneously in plants. In addition to its participation as a plant growth regulator, JA plays an important role in plant defense, acting as an intracellular signal transducer and an inducer of defense gene transcription (6). JA is synthesized from oxylipin pathway and is induced by abiotic and biotic stresses, such as injury, osmotic stress, pathogen attack and elicitor treatment. JA action is thought to be mediated by a still unknown JA-receptor. The pathogenesis-related proteins PR-2 (â-glucanases), PR-3 and PR-4 (chitinases), PR-5 (thaumatin-like proteins), PR-6 (proteinase inhibitor), PR-10 (ribosomal inhibitor proteins), HRGP (extensions) and cyclophilins are defensive proteins known to be jasmonateinduced. The first compound metabolized in JA biosynthesis is alinolenic acid (LA). The major source of LA are plastid membranes; it is also a substrate for lipoxygenase (LOX). In the FORESTs database, we found a high similarity of LOX to other dicotyledonous LOX such as those of $A$. thaliana and potato (Table 2). LOX was expressed in most sugarcane tissues, although at higher amounts only in roots or plants infected with bacteria (28).

The next step in JA biosynthesis is the formation of allene oxide through the enzymes allene oxide synthase (AOS) and allene oxide cyclase (AOA). AOS is highly homologous to AOS from tomato. AOS and AOA homologous enzymes were identified in the FORESTs database (Table 2).

\section{Detoxification genes and reactive oxygen species}

As regards the enzyme Glutathione S-transferase (GST), McGonigle et al., (31) concluded that a high level of hydrogen peroxide induced a great increase in the enzyme's mRNA in soybean cells. Most GSTs found in plants were isolated as a result of their induction by several treatments, including indole-acetic acid, ethylene, herbicides, infection by pathogens, intoxication by heavy metals, and high temperatures (31). Several GSTs were identified in a variety of plant species, and their complete sequence of primary amino acids was determined. Homologous genes associated with GST were identified by comparing the data available in NCBI and GeneBank databases with those available in the sequence database of FORESTs project. Considering GST enzyme, clusters EGRFST2233B11.g were selected since they showed the best e-values, as well as the best identity, when compared among different organisms (Table 3).

According to Scandalios (42), the evolutionary origin of Superoxide Dismutase (SOD) is not clear; however, the available information suggests that the three existing types of SOD are included in two phylogenetic families, $\mathrm{Cu} / \mathrm{ZnSOD}$ and Fe-/MnSODs. FeSODs and MnSODs are closely related since they share a high degree of identity between their amino acid sequences and homologous structures but are not related to $\mathrm{Cu} / \mathrm{ZnSODs}$.

When a plant enters senescence, the activities of all SODs and other oxygen-detoxifying enzymes (such as catalase and glutathione reductase) decrease. Such observations are consistent with the proposition that free radicals play an important role in senescence and in the process of aging. Homologous genes associated with $\mathrm{Fe} /$ SOD were identified by comparing the data available in NCBI and GenBank databases with those in the sequence database of the FORESTs project. Clusters EGEQRT3100G07.g and EGEZRT3005F09.g were selected since they showed the best e-values, as well as the best identity, when compared among different organisms (Table 3). The similarity between sequences from clusters and the selected organisms can be observed for the species Arabidopsis thaliana and Raphanus sativus.

Peroxidase can be considered a biochemical stress marker resultant of both biotic and abiotic factors. According to Gaspar et al. (17), peroxidase is the key molecule in the adaptation of plants or some of their organs individually to environmental changes. Homologous genes associated with peroxidase were identified by comparing the data available in NCBI and GeneBank databases with those in the sequence database of the FORESTs project. Cluster EGEQST2200H09.g was selected since it showed the best e-values, as well as the best identity, when compared to A. thaliana (Table 3).

Catalase (CAT), a metalloprotein in the group of porphyrins, is found in all aerobic organisms and catalyzes hydrogen peroxide dismutation, converting it into water and molecular oxygen. Homologous genes associated with CAT were identified by comparing the data available in NCBI and GeneBank databases with those in the sequence database of the FORESTs project. Cluster 
Table 3. Eucalyptus putative homologous genes involved with detoxification of reactive oxygen species (ROS).

\begin{tabular}{|c|c|c|c|c|}
\hline Putative genes & Species & FORESTs number & NCBIAccession & E-value \\
\hline Superoxide dismutase [Mn] & Zea mays & EGEZSL8253H05.g & 7548002 & $5 \mathrm{e}^{-96}$ \\
\hline Superoxide dismutase $(\mathrm{Cu}-\mathrm{Zn})$ & Raphanus sativus & EGFFB 1039E04.b & AAL07333 & $2 \mathrm{e}^{-101}$ \\
\hline Superoxide dismutase[cu-zn] 4A - cytosolic & Zea mays & EGCCST6227F01.g & 6018746 & $6 \mathrm{e}^{-74}$ \\
\hline Glutathione S-transferase GST 10 & Glycine $\max$ & EGBMLV2260C10.g & AAG34813 & $3 \mathrm{e}^{-102}$ \\
\hline Glutathione S-transferase GST & Arabidopsis thaliana & EGRFST2233B11.g & 11967658 & $6 e^{-76}$ \\
\hline Glutathione S-transferase GST & Capsicum annuum & EGRFST2233B11.g & 24061761 & $3 e^{-83}$ \\
\hline Putative phospholipid hydroperoxide glutathione & Oryza sativa & EGSBRT3123D01.g & gi|11545686 & $4 \mathrm{e}^{-70}$ \\
\hline Peroxidase & Arabidopsis thaliana & EGEQST2200H09.g & AAN31858 & $5 e^{-120}$ \\
\hline GPX12Hv -glutathione peroxidase-like protein & Hordeum vulgare & EGRFST6257E07.g & gi|6179600 & $4 \mathrm{e}^{-79}$ \\
\hline Glutathione peroxidase & Arabidopsis thaliana & EGRFST6270H10.g & gi|20465389 & $3 e^{-69}$ \\
\hline \multirow[t]{2}{*}{ Catalase } & Pisum sativumZea mays & EGEQLV1201F10.g & CSPM & 0.0 \\
\hline & & EGEZLV3268A11.g & 168437 & $1 \mathrm{e}^{-134}$ \\
\hline
\end{tabular}

EGEQLV1201F10.g was selected since it showed the best e-values, as well as the best identity, when compared to Pisum sativum (Table 3).

\section{Phytoalexins}

Phytoalexins are low molecular weight antimicrobial compounds produced by plants as a result of stress or infection. They are located around the infection site and the speed and magnitude at which they are produced and accumulate appear to determine the disease reaction in some interactions of plants with fungi and bacteria (27). Phytoalexins are produced in plants according to their botany families but isoflavonoids, sesquiterpenoids, polyacetylens and furanosequiterpenoids predominate. There are 102 phytoalexins reported for Leguminosae: 84 isoflavonoids; 8 furanoacetylenes, 4 stilbenes, 3 benzofurans, 2 chromones and 1 flavones. Three basic pathways for the biosynthesis of secondary metabolites in plants are the acetatemalonate, acetate-mevalonate and shikimate (27).
The synthesis of phytoalexins in plants is associated with the general metabolism of phenylpropanoids, including enzymes related to other processes, such as PAL, caffeic acid 3-O-methyltransferase (COMT) and 4-coumarate CoA ligase (4CL). This process also has specific enzymes such as chalcone synthase (CHS), chalcone isomerase (CHI), isoflavanone synthase (IFS), and isoflavone reductase (IFR). PAL is the first and a key regulatory enzyme in the metabolic pathway of phenylpropanoids; it catalyzes the deamination of L-phenylalanine to produce trans-cinnamic acid, leading to the formation of a wide range of secondary metabolites (43). In the FORESTs database, we found clusters similar to PAL (Table 4) and the enzymes COMT, 4CL, CHS, CHI, IFS, IFR involved in phytoalexin biosynthetic pathway.

\section{Pathogenesis-related proteins (PR-Proteins)}

PR-1 is the most abundant PR protein and is induced in infected plant tissue (2). PR-1 genes are expressed due to various external

Table 4. Eucalyptus putative homologous genes involved with the pathway of secondary compounds.

\begin{tabular}{|c|c|c|c|c|}
\hline Putative genes & Species & FORESTs number & NCBIAccession & E-value \\
\hline Phenylalanine ammonia-lyase & Nicotiana tabacum & EGJFCL4208B06.g & 2564057 & $1 \mathrm{e}^{-143}$ \\
\hline Enol piruvil shiquimate 3 fosfato sintase & Brassica napus & EGEQRT3102H01.g & $\mathrm{P} 17688$ & 0.0 \\
\hline Phenylalanine ammonia-lyase - PAL & Eucalyptus spp. & EGCCSL5065E07.g & 5690433 & $4 e^{-122}$ \\
\hline Quercetina 3-O-methyltransferase & Arabidopsis thaliana & EGEQRT3104D08.g & Q9FK25 & $2 \mathrm{e}^{-168}$ \\
\hline 4-coumarate-CoA ligase & Glicine $\max$ & EGEQRT3001EO7.b & AAC 97600 & 0.0 \\
\hline cinnamyl-Co-A reductase & Pinus taeda & EGEQRT5001C10.g & AAL47684 & $5 \mathrm{e}^{-132}$ \\
\hline cinnamyl-alcohol dehydrogenase & Medicago sativa & EGEQFB 1004E07.g & AAL34329 & $6 e^{-126}$ \\
\hline 4-hydroxycinnamic acid-CoA ligase & Sorghum bicolor & EGJFWD2321C04.g & 763046 & $2 e^{-71}$ \\
\hline Chalcone synthase 6 & Sorghum bicolor & EGJEWD2308B10.g & 5305917 & $3 e^{-115}$ \\
\hline Flavone hydroxilase & Arabidopsis thaliana & EGACRT6209G11.g & 6979554 & $1 e^{-147}$ \\
\hline Isoflavone reductase (IFR)) & Zea mays & EGCCRT6013E03.g & gi|1205986 & $2 \mathrm{e}^{-86}$ \\
\hline
\end{tabular}


stimuli like pathogens, injury, chemical elicitors, hormones, UV light (9) and salicylic acid. PR-1 proteins contain a hydrophobic N-terminal region of 30 amino acids that probably function as a signal peptide for the translocation to the endoplasmic reticulum (38). The FORESTs database has sequences (EGSBRT3122B04.g and EGBMCL1291G04.g) similar to C. annum PR-1 and a precursor protein of maize, respectively (Table 5).

PR-2 can act directly or indirectly against pathogens: directly by degrading the pathogen's cell wall glucan, the major wall component of many pathogenic fungi (55), and indirectly by promoting the release of oligosaccharides from the pathogen's cell walls, which can act as elicitors of defense reactions (8). PR-2 corresponds to b-1,3-glucanases (glucan endo b-1,3 glucosidases) capable of catalyzing endo-type hydrolytic cleavage of b-1,3-D-glucosidic linkages in b-1,3- glucans. b-1,3-glucanases (bGlu) are abundant proteins implicated in plant defense mechanisms, as well as in several physiological processes of healthy plants.

PR-2 proteins are classified into three different structural classes (32): a) Class bGlu I comprises basic proteins located in the cell vacuole and accumulated at higher concentrations in the roots and at lower levels in mature leaves of healthy tobacco plants.

b) Classes bGlu II and bGlu III are secreted into the extracellular space.

We found four clusters of high similarity; these clusters of the PR-2 or Beta-1,3-glucanase family were similar to proteins of Fragaria X Ananassa, Prunus persica; Hevea brasiliensis, and A. thaliana (Table 5).

PR-3, PR-4, PR-8, PR-11 (Chitinases) are ubiquitous enzymes of bacteria, fungi, animals and plants. They hydrolyze the b-1,4-linkage between $N$-acetylglucosamine residues of chitin, a structural polysaccharide of the cell wall of a number of fungi.

PR-3 subgroup includes several classes of chitinase and all of them have chitin-binding domain (CBD). The family class is classified according to homologous sequences and presence/absence of a particular binding site. Six classes of PR-3 have been described based on amino acid sequence homology: Classes I, II, IV, V, VI and VII (37). Most class I chitinases have a C-terminal pro-peptide necessary for

Table 5. Eucalyptus putative homologous genes involved with PR-proteins.

\begin{tabular}{|c|c|c|c|c|}
\hline Putative genes & Species & FORESTs number & NCBIAccession & E-value \\
\hline PR-1 & Capsicum annиum & EGSBRT3122B04.g & gi|13560653 & $4 e^{-58}$ \\
\hline PR-1 Maize PRMS precursor & Zea mays & EGBMCL1291G04.g & gi|130940 & $5 \mathrm{e}^{-41}$ \\
\hline PR-2 Beta-1,3-glucanase & Prunus persicae & EGEQST2201A05.g & gi|16903144 & $2 \mathrm{e}^{-142}$ \\
\hline PR-2 Beta-1,3-glucanase & Hevea brasiliensis & EGEQRT5001D04.g & gi|4469115 & $3 \mathrm{e}^{-107}$ \\
\hline PR-2 Beta-1,3-glucanase precursor & Arabidopsis thaliana & EGBFSL1080G08.g & gi|21554264 & $4 e^{-79}$ \\
\hline Beta-glucan binding protein (GEBP) & Phaseolus vulgaris & EGEZST2207F06.g & gi|6625560 & $8 e^{-90}$ \\
\hline Beta-glucan binding protein (GEBP) & Glycine $\max$ & EGEZST2207F06.g & gi|5019452 & $1 \mathrm{e}^{-102}$ \\
\hline PR-3- chitinase & Vitis vinifera & EGEQFB1001F10.g & gi|10880381 & $1 \mathrm{e}^{-121}$ \\
\hline PR-3 Class I & Gossypium hirsutum & EGMCST2239D03.g & gi|4205741| & $1 \mathrm{e}^{-142}$ \\
\hline PR-3 Class I & Gossypium hirsutum & EGEQRT5001D01.g & gi|4205741| & $1 \mathrm{e}^{-158}$ \\
\hline PR-3 Class I & Arabis holboelli & EGEQRT5002A03.g & gi|7798632| & $2 \mathrm{e}^{-102}$ \\
\hline PR-3 Class IIa & Gossypium hirsutum & EGEQFB1001F10.g & gi|7435351| & $1 \mathrm{e}^{-124}$ \\
\hline PR-3 Class IV & Daucus carota & EGEZST7212C03.g & gi|7435371| & $3 e^{-120}$ \\
\hline PR-3 Class V & Nicotiana tabacum & EGEQRT3300H12.g & gi|505267 & $3 e^{-142}$ \\
\hline PR-4 Class I & Vitis vinifera & EGMCST2237F11.g & gi|351147| & $5 \mathrm{e}^{-137}$ \\
\hline PR-5 thaumatin-like protein & Helianthus annuus & EGEQRT5002e12.g & gi|20385169 & $4 \mathrm{e}^{-103}$ \\
\hline PR-5 thaumatin-like protein & Zea mays & EGJECL2209E10.g & gi|444344 & $1 \mathrm{e}^{-35}$ \\
\hline PR-6 cysteine proteinase inhibitor & Glycine $\max$ & EGEQFB1001F12.g & gi|1944319 & $2 \mathrm{e}^{-81}$ \\
\hline PR-6 cysteine proteinase inhibitor & Oryza sativa & EGEQST6002D02.g & gi|6721552 & $1 \mathrm{e}^{-78}$ \\
\hline PR-7 aspartic proteinase & Nepenthes alata & EGEZST2207H05.g & gi|12231174 & 0.0 \\
\hline PR-7 oryzasin & Oryza sativa & EGEZSL4258G07.g & gi| 2130068 & $1 \mathrm{e}^{-114}$ \\
\hline PR-7 Aspartic Proteinase & Oryza sativa & EGABFB 1099H07.g & gi| 82458 & $1 \mathrm{e}^{-102}$ \\
\hline PR-8 Class III (chitinase) & Oryza sativa & EGJELV2266H01.g & gi|27817953 & $1 \mathrm{e}^{-106}$ \\
\hline PR-8 Class III & Fragaria x Ananassa & EGJELV2266H01.g & gi|4530607| & $4 \mathrm{e}^{-98}$ \\
\hline PR-9 Peroxidase, putative & Arabidopsis thaliana & EGEQRT3201E09.g & gi|15239370 & $3 \mathrm{e}^{-139}$ \\
\hline PR-9 Peroxidases & Oryza sativa & EGEQCL1341G06.g & gi|7242902 & $1 \mathrm{e}^{-102}$ \\
\hline PR-9 Peroxidases & Arabidopsis thaliana & EGEQCL1341G06.g & gi|10177520 & $2 \mathrm{e}^{-106}$ \\
\hline PR-9 Peroxidases & Triticum aestivum & EGEZFB1045A11.g & gi|2117619 & $6 \mathrm{e}^{-81}$ \\
\hline PR-10 Ribonuclease-like proteins & Castanea sativa & EGEQCL1200H04.g & gi|16555781 & $1 \mathrm{e}^{-53}$ \\
\hline PR-10 Ribonuclease-like proteins & Vitis vinifera & EGEQSL1050E09.g & gi|11182124 & $2 \mathrm{e}^{-46}$ \\
\hline PR-10 Ribonuclease-like proteints & Sorghum bicolor & EGEQCL1500C08.g & gi|1408222 & $7 e^{-20}$ \\
\hline
\end{tabular}


their targeting to the vacuole. There were seven clusters of high similarity to PR-3 chitinases in the FORESTs bank (Table 5). Four Eucalyptus clusters were similar to class I chitinase of Gossypium hirsutum and Arabis holboelli, one cluster was similar to class IIa chitinase of Gossypium hirsutum and another cluster to class IV chitinase of Daucus carota. Class I chitinases are associated with the biochemical defense of plants against potential pathogens (10). Class IIa chitinase is pathogen-induced and, according to Huynh et al. (20), this chitinase showed greater antifungal activity when tested in vitro against the growth of Trichoderma reesei, Alternaria solani, and Fusarium oxysporum. Class IV chitinases are also induced by pathogens and by salicylic acid treatment; they were expressed during leaf senescence in Brassica napus (18).

Among the Eucalyptus clusters, three were analyzed according to the similarity of predicted amino acids to classes I, II and IV of PR-3 from dicots. Two clusters showed absence of twenty-one amino acids at the N-terminal region, which represents a signal region, and had the stop codon at the $\mathrm{C}$-terminal region. The predicted amino acids of these clusters aligned with class I chitinase of cotton at $75-78 \%$ similarity. The predicted amino acid sequences of these Eucalyptus clusters contain cysteine-rich $\mathrm{N}$-terminal domains with eight conserved cysteine residues that are essential for chitin binding (45) or improve the chitin-hydrolyzing activity of chitinases (56). Another Eucalyptus cluster was similar to class IV chitinase with translational start site of the major open reading frame (ORF) and stop site. The nucleotide sequence of cDNA encodes a predicted 274-amino acid protein containing $81 \%$ of conserved amino acids for a class IV chitinase of Daucus carota. This Eucalyptus cluster contains cysteine-rich Nterminal domains and is smaller due to deletions when compared to class I chitinases. The Eucalyptus cluster also had the amino acid Tyr182 , which is the active site of the predict class IV chitinase (20).

PR-4 family is divided into classes I and II. Class I is represented by hevein, a small anti-fungal protein found in Hevea brasilienses (52). Hevein has a three-dimensional structure similar to domains of wheat-germ agglutinin and other cereal lectins. The sequence precursor is highly homologous to cDNA encoding for an injury-induced protein (called Win) of potato. The Eucalyptus database contains EST clusters homologous to class I PR-4 of Vitis vinifera (Table 5). Two clusters showed above $76 \%$ similarity to grapevine and barley seed basic protein, which presents similarity to the proteins encoded by the injury-induced potato and rubber tree genes.

PR-8 includes chitinases belonging to class III, which in turn belong to the family 18 of glycosyl hydrolases (36). These pathogenesisrelated proteins were first described as lysozymes and were isolated from Parthenocissus quinquifolia and cucumber (34). They were also isolated from Hevea brasiliensis latex, as heveamine, a dual lysozime and chitinase (21). In plants, PR-8 has been induced by pathogen infection in Arabidopsis (44), tobacco (30), barley (23), and cucumber (30), as well as by injury in cucumber (29).

Class III chitinase can also be induced by pathogens, such as in Cucubita maxima, in which Neurospora crassa induced the expression of class III chitinase (25). Although the predicted Eucalyptus proteins are full-length, they lack in their sequences the N-terminal cysteinerich domain, a predominant characteristic of class III chitinases from plants (25). The amino acid residues at the putative catalytic site of the plant class III chitinases, aspartic acid and glutamic acid, are present at amino acid positions 129 and 149 (aspartic acid), and 133 and 153 (glutamic acid) in Eucalyptus predicted proteins similar to class III chitinases of rice and Hevea, respectively.
PR-11 was first isolated from tobacco (33) and also belongs to family 18 of glycosyl hydrolases (36). This protein is induced by pathogen infection and shares very little sequence homology with PR-8 and other plant chitinases, even though it presents the basic protein structure.

Two clusters were similar to class III chitinase (Table 5). One of these clusters was $80 \%$ similar to class III chitinase from Oryza sativa and less similar to classes of PR-3 chitinases. Another Eucalyptus cluster showed $81 \%$ similarity to class III chitinase from Fragaria $x$ Ananassa.

PR-5 (thaumatin-like) proteins were first detected in acidic extracts of tobacco leaves infected with Tobacco mosaic virus (TMV) (40). Because of their high similarity to the sweet-tasting protein thaumatin from Thaumatococcus daniellii, these proteins were called thaumatinlike proteins (TLPs). Osmotin and NP24 are also related to thaumatin and accumulate in cultured tobacco and tomato cells, respectively, under osmotic stress. Since these two proteins are induced by pathogen infection, they also belong to PR-5 family (47). It has been shown that TLPs have anti-fungal properties and are part of the plants' antifungal defenses (54). In the FORESTs database, there is a putative PR-5 similar to PR-5 of maize and sunflower (Table 5).

PR-6, proteinase inhibitors (PIs), was first isolated from seeds of Fabaceae, Poaceae, and Solanaceae (41). These are highly stable defensive proteins of plant tissues that are both developmentally regulated and induced in response to insect and pathogen attacks. PRs form structurally unrelated subclasses, with various regulations, affecting all types of proteolytic enzymes (serine-, cysteine-, aspartic, and metallo-proteinases). Proteolytic enzymes are part of the virulence factor of pathogenic organisms and their inhibition may limit the availability of the amino acid source for the invader, among other effects. The inhibitory activity of proteinase was described for a number of plant-pathogen interactions including viruses, bacteria and fungi (11). The induction of PR-proteins by insect or other mechanical injuries have been described for interaction with potato, maize, tomato, wheat and alfalfa. Five main factors can induce systemic expression of PRs: systemin, abscisic acid (ABA) or JA. Recently, tomato pin2 (proteinase inhibitor 2) gene was shown to be ABAindependent for systemin induction. In the eucalypt EST database, there are two clusters (EGJQFB1001F12.g and EGEQST6002D02.g) similar to Glycine max and Oryza sativa, respectively.

PR-7 family has as one of its members an alkaline proteinase (PRP69) and isoforms expressed in tomato after pathogen infection (22). Tobacco leaves were found to constitutively express an extracellular aspartyl-proteinase of $36-40 \mathrm{kDa}$ which cleaves PR proteins under acidic conditions, these proteinases may be involved in the regulation of PR proteins, deactivation and recycling. In the FORESTs database, there are sequences similar to putative rice orizasin and aspartylprotease precursor (Table 5).

PR-9 peroxidases are heme-containing glycoproteins that catalyze the oxidation by $\mathrm{H} 2 \mathrm{O} 2$ of a wide range of organic and inorganic substrates. They occur in numerous isoforms in plants, animals, fungi and bacteria (17). In plants, peroxidases are key enzymes in wallbuilding processes like cross-linking of polysaccharides and extensin phenylpropanoid monomers, as well as in suberization. In addition, specific isoenzymes, similar to a lignin-forming peroxidase, were recognized as PRs in tobacco and were classified as PR-9 (47).

Considering the wide variety of known peroxidase genes, our efforts concentrated on finding EST clusters similar to driver sequences associated with pathogen interactions and related situations. We have 
found putative homologs to PR-9 of rice, wheat and Arabidopsis (Table 5) in the FORESTs databank.

PR-10 family has as its characteristic member a protein isolated from parsley which shares structural homology with ribonucleases (46). Proteins of the PR-10 family seem to be ubiquitous in plants, occurring in several plant species. Allergens from birch pollen grains, apple, and celery share sequence homologies with PR-10 family and are also included in this class. PR-10 proteins accumulate around sites of pathogen entry and injury; plant hormones (cytokinins, ABA, and ethylene) also induce the production of PR-10 transcripts. PR-10 can be present in seeds, roots, stem, flowers and senescent leaves. In the FORESTs, we found two clusters similar to PR-10: Vitis vinifera and Sorghum bicolor (Table 5). EST sequencing allows the analysis of expressed genes and has accelerated gene discovery, in addition to the establishment of putative functions through comparisons of ESTs with genes and sequences, the functions of which are already known to include important defense mechanisms.

\section{REFERENCES}

1. Agrios, G.N. Plant pathology. New York: Academic Press, 1997. $635 \mathrm{p}$.

2. Alexander, D.; Goodman, R.M.; Gut Rella, M.; Glascock, C.; Weymann, K.; Friedrich, L.; Maddox, D.; Ahl Goy, P.; Luntz, T.; Ward, E.; Ryals, J. Increased tolerance to two oomycete pathogens in transgenic tobacco expressing pathogenesis-related protein. 1a. Proceedings of the National Academy of Sciences of the United States of America, Washington, v. 90, 1993.

3. Altschul S.F., Madden T.L., Schaffer A.A., Zhang J., Zhang Z., Miller W. And Lipman D.J. (1997). Gapped BLAST and PSIBLAST: a new generation of protein database search programs. Nucleic Acids Res., v. 25, p.3389-3402, 1997.

4. Baker, B.; Zambryski, P.; Staskawicz, B.; Dinesh-Kumar, S.P. Signaling in plant-microbe interactions. Science, 276(5313): 726-733, 1997.

5. Bent, A.F.; Kunkel, B.N.; Dahlbeck, D.; Brown, K.L.; Schimidt, R.; Giraidat, J.; Leung, J.; Staskawicz, B.J. RPS2 of Arabdopisis thaliana: a Leucine-rich repeat class of plant diseases resistance genes. Science, v.265, p.1856-60, 1994.

6. Blechert, S.; Brodschelm, W.; Holder, S.; Krammerer, L.; Kutchan, T.M.; Muller, M.J.; Xiaz, Q.; Zenk, M.H. Octadecanoid pathway: signal molecules for the regulation of secondary pathway. Proceedings of the National Academy of Sciences of the United States of America, Washington, v.92, n.10, p. 40994105, 1995.

7. Boller, T. Antimicrobial functions of the plant hydrolases chitinase and B-1,3-glucanase. In: Fritig, B.; Legrand, M. Ed. Developments in plant pathology, 1993. p. 391-400.

8. Bowles, J.D. Defense-related proteins in higher plants. Annual Review of Biochemistry, v.59, p. 873-907, 1990.

9. Brederode, F.T.; Linthorst, H.J.M.; Bol, J.F. Differential induction of acquired resistance and PR gene expression in tobacco by virus infection, ethephon treatment, UV light and wounding. Plant Molecular Biology, v. 17, n. 6, p. 1117-1125, 1991.

10. Chang, M. M., Horovitz, D., Culley, D.; Hadwiger, L. A. Molecular cloning and characterization of a pea chitinase gene expressed in response to wounding, fungal infection and the elicitor chitosan. Plant Molecular Biology, v. 28, p. 105-111. 1995.

11. Cordero, M.J.; Raventós, D.; San Segundo, B. Expression of a maize proteinase inhibitor gene is induced in response to wounding and fungal infection: systemic wound-response of a monocot gene. Plant Journal, v. 6, n. 1, p. 141-150, 1994.

12. Dixon, R. A.; Lamb, C. J. Molecular communication in interactions between plants and microbial pathogens. Annual Review of Plant Physiology and Plant Molecular Biology, v. 41, p.339-367, 1990.

13. Ecker, J.R. The ethylene signal transduction pathway in plants. Science, v. 268, n. 1, p. 667-675, 1995.

14. Feuillet, C.; Schachermayr, G.; Keller, B. Molecular cloning of a new receptor-like kinase genes encoded at the Lr10 disease resistance locus of wheat. The Plant Journal, v. 11, n. 1, p. 45-92, 1997.

15. Flor, H.H. Genetics of pathogenicity in Melampsora lini. Journal Agricultural Research, v. 73, p. 335-337, 1946.

16. Forests - Eucalyptus ESTs Genome Sequencing Project Consortium. Disponível em: 〈https://forest.esalq.usp.br>. Acesso em: oct $24^{\text {th }} .2007$.

17. Gaspar, T.; Penel, C.; Thorpe, T.; Greppin, H. Peroxidases: a survey of their biochemical and physiological roles in higher plants. Geneve: University of Geneva Press, 1982, 324p.

18. Hanfrey, C.; Fife, M.; Buchanan-Wollaston, V. Leaf senescence in Brassica napus: expression of genes encoding pathogenesisrelated proteins. Plant Mol. Biol. v. 30, p. 597-609. 1996.

19. Hillier, L.; Lennon, G.; Becker, M.; Bonaldo, M.F.; Chiapelli, B.; Chissoe, S.; Deitrich, N.; Dubuque, T.; Favello, A.; Gish, W. Generation and analysis of 280,000 human expressed sequence tags. Genome Research, v. 6, n. 9, p. 807-828, 1996.

20. Huynh, Q. K.; Hironaka, C. M.; Levine, E. B.; Smith, C.E.; Borgmeyer, J. R.; Shah, D. M. Antifungal proteins from plants. Purification, molecular cloning, and antifungal properties of chitinases from maize seed. J. Biol. Chem. v. 267, p. 6635-6640. 1992.

21. Jekel, P.A.; Hartmann, J.B.H.; Beintema, J.J. The primary structure of hevamine, and enzyme with lysozyme/chitinase activity from Hevea brasiliensis latex. Eur. J. Biochem. v. 200, p. 123. 1991.

22. Jorda, L.; Coego, A.; Conejero, V.; Vera, P. A genomic cluster containing four differentially regulated subtilisin-like processing protease genes is in tomato plants. The Journal of Biological Chemistry, v. 274, n. 4, p.2360-2365, 1999.

23. Kragh K.M., Jacobsen S., Mikkelsen J.D., Nielsen K.A. Tissue specificity and induction of class I, II, III chitinases in barley (Hordeum vulgare). Physiol. Plant, v. 89, p. 490-498, 1993.

24. Kieber J.J.; Rothenber,G.M.; Roman, G.; Feldmann, K.A.; Ecker, Jr. CTR1, a negative regulator of the ethylene response pathway in Arabidopsis, encodes a member of the raf family of protein kinases. Cell, v. 72, p. 427-441. 1993.

25. Kim, M. G.; Lee, K. O.; Cheong, N. E.; Choi, Y. O.; Jeong, J. H.; Cho, M. J.; Kim, S. C.; Lee, S. Y. Molecular cloning and characterization of a class III chitinase in pumpkin leaves, which strongly binds to regenerated chitin affinity gel. Plant Sci. v. 147, p. 157-163. 1999.

26. Kolattukudy, P.E. Cutin, suberin and waxes. In: The biochemistry of plants. Academic Press, 1980, p. 571-635. 1980.

27. Kuc, J. Induced systemic resistance to plant disease and phytointerferons - are compatible? Fitopatologia brasileira, v. 10, n. 1, p. 17-40, 1985.

28. Kuramae, E.E.; Fenille, R.C.; Rosa Jr., V.E.; Rosa, D.D.; Monteiro, J.P.; Gimenes, M.A.; Palmieri, D. A.; Lima, M.M.; Fávaro, R.D. Mining of sugarcane ESTs involved in the mechanisms against plant pathogen and envinmental stress. Summa Phytopathologica, Botucatu, v. 28, p.315-324, 2002.

29. Lawton, K.A.; Beck, J.; Potter, S.E.; Ward, A.C.; Ryals, J. Regulation of cucumber class III chitinase gene expression. Mol. Plant-Microbe Interact. v. 7, p. 48. 1994.

30. Lawton, K.; Ward, E.; Payne, G.; Moyer, M.; Ryals, J. Acidic and basic class III chitinase mRNA accumulation in response to TMV infection of tobacco. Plant Mol. Biol. v. 19, p. 735-739. 1992.

31. Mcgonigle B.; Lau, S.C.; Jennings, L.D.; O'Keefe, D.P. Homoglutathione selectivity by soybean glutathione S-transferase. Pest. Biochem. And Physiol., p. 15-25, 1998.

32. Meins, F., Jr.; Neuhaus, J.M.; Sperisen, C.; Ryals, J. The primary structure of plant pathogenesis-related glucanohydrolases and their genes. In: Boller, T., Meins Jr., F. (Eds.) Genes involved in plant defense. Vienna: Springer-Verlag, 1992, p.245-282. 
33. Melchers, L. S.; Apotheker-De Groot, M.; Van Der Knaap, J.; Ponstein, A. S.; Sela-Buurlage, M. B., Bol, J. F., Cornelissen, B. J. Z.; Van Den Elzen, P. J. M.,; Linthorst, H. J. M. A new class of tobacco chitinases homologous to bacterial exo-chitinases displays antifungal activity. Plant J. v. 5,, p. 469. 1994.

34. Métraux, J.P.; Ahl Goy, P.; Staub, T.; Spelch, J.; Steinemann, A.; Ryals, J.; Ward, E. Induced resistance in cucumber in response to 2,6-dichloroisonicotinic acid and pathogens. In: Hennecke, H.; Verma, D.P.S. (Ed.). Advances in molecular genetics of plantmicrobe interactions, 1991 , v.1. p. 432-439.

35. Neiman, A.M. Conservation and reinteration of a kinase cascade. Trends Genetics, v. 9, p. 390-394, 1993.

36. Neuhaus, J-M. Plant chitinases (PR-3, PR-4, PR-8, PR-11). In: Datta, S.K., Muthukrishnan, S. (Ed.) Pathogenesis-related proteins in plants. New York: CRC Press, 1999, p.77-105.

37. Ohme-Takagi, M.; Shinshi, H. Ethylene-inducible DNA binding proteins that interact with an ethylene-responsive element. Plant Cell, v. 7, n. 2, p. 173-182, 1995.

38. Payne, G.; Middlesteadt, W.; Desai, N.; Williams, S.; Dincher, S.; Carnes, J.; Ryals, J. Isolation and sequence of a genome clone encoding the basic form of pathogenesis-related protein 1 from Nicotiana tabacum. Plant Molecular Biology. v. 12, n. 5, p. 595-596, 1989.

39. Parker, J.E.; Coleman, M.J.; Szabò, V.; Frost, L.N.; Schmidt, R.; Van Der Biezen, E.A.; Moores, T.; Dean, C.; Daniels, M.J.; Jones, J.D.G. The Arabidopsis downy mildew resistance gene RPP5 shares similarity to the Toll and interleukin-1 receptors with $\mathrm{N}$ and L6. Plant Cell, v. 9, n. 6, p. 879-894, 1997.

40. Pierpoint, W.S.; Tatham, A.S.; Pappin, D.J.C. Identification of the virus-induced protein of tobacco leaves that resembles the sweet-tasting protein thaumatin. Physiological and Molecular Plant Pathology, v. 31, n. 1, p.291-298, 1987.

41. Ryan, C.A. Protease inhibitors in plants: genes for improving defenses against insects and pathogens. Annual Review of Phytopathology, v. 28, p. 425-449, 1990.

42. Scandalios, J.G. Oxygen stress and superoxide dismutases, Plant Physiol. v.101, p. 7-12. 1993.

43. Sharan, M.; Taguchi, G.; Gonda, K.; Jouke, T.; Shimosaka, M.; Hayashida, N.; Okasaki, M. Effects of methyl jasmonate and elicitor on the activation of phenylalanine ammonia-lyase and the accumulation of scopoletin and scopolin in tobacco cell cultures. Plant Science, v. 132, n. 1, p. 13-19, 1998.

44. Samac, D. A.; Shah, D. M. Developmental and pathogen induced activation of the Arabidopsis acidic chitinase protein. Plant Cell, v. 3, p. 1063-1072, 1991.

45. Shinshi, H.; Neuhaus, J. M., Ryals, J.; Mein, F. Structure of a tobacco endochitinase gene: evidence that different chitinase gene can arise by transposition of sequence encoding a cysteine-rich domain. Plant Mol. Biol. v. 14, p. 357-368. 1990.

46. Sikorski, M.M., Biesiadka, J., Kasperska, A.E., Kopcinska, J., Lotocka, B., Golinowski, W., Legocki, A.: Expression of genes encoding PR10 class pathogenesis-related proteins is inhibited in yellow lupine root nodules. Plant Sci. v. 149,, p. 125-137, 1999.

47. Stintzi, A.; Heitz, T.; Prasad, V.; Wiedemann-Merdinoglu, S.; Kauffmann, S.; Geoffroy, P.; Legrand, M.; Fritig, B. Plant "pathogenesis-related" proteins and their role in defense against pathogens. Biochimie, v. 75, n. 3, p. 687-706, 1993.

48. Suzuki, K.; Suzuki, N.; Ohme-Takagi, M.; Shinshi, H. Immediate early induction of mRNAs for ethylene-responsive transcription factors in tobacco leaf strips after cutting. Plant Journal, v. 15, n. 5, p.657-665, 1998.

49. Sweigard, J.A; Chunley, F.G.; Valent, B. Disruption of a Magnaporte grisea cutinase gene. Molecular Genetics and Genomics, v. 232, p. 183-190, 1992.

50. Uchiana, T. \& Okuyama, K. Participation of Oryza sativa leaf wax in appressorium formation by Pyricularia oryzae. Phytochemistry, v. 29, p. 91-92, 1990.

51. Van Loon, L.C. Occurrence and properties of plant pathogenesis-related proteins. In: Datta, S.K.; Muthukrishnan, S. (Ed.) Pathogenesis-related proteins in plants. New York: CRC Press, 1999, p.1-19.

52. Van Parijs, J.; Broekaert, W.F.; Peumans, W.J. Hevein: an antifungal protein from rubber-tree (Hevea brasliensis) latex. Planta, v. 183 , n. 1, p. 258-264, 1991.

53. Verberne, M.C.; Verpoorte, R.; Bol, J.F.; Mercado-Blanco, J.; Linthorst, H.J.M. Overproduction of salicylic acid in plants by bacterial transgenes enhances pathogen resistance. Nature Biotechnology, v. 18 , n. 2, p. 779-783, 2000.

54. Vigers, A.J.; Roberts, W.K.; Selitrennikoff, C. P. A new family of plant antifungal proteins. Molecular Plant-Microbe Interactions, v. 4, n. 2, p. 315-323, 1991.

55. Wessels, J.G.H.; Sietsma, J.H. Fungal cell walls: a survey. In: Tanner, W., Loewus, F.A. (Ed.) Encyclopedia of plant physiology. Plant Carbohydrates II. Berlin: Springer Verlag, 1981, 352p.

56. Yamagami, T. \& Funatsu, G. Limited proteolysis and reduction carboxylmethylation of rye seed chitinase-?: role of the chitinbinding domain in its chitinase action. Biosci. Biotechnol. Biochem. v. 60, p. 1081-1086. 1996. 